\title{
Simulating vertical flow wetlands using filter media with different grain sizes with the HYDRUS Wetland Module
}

\author{
Bernhard Pucher*, Guenter Langergraber \\ Institute of Sanitary Engineering and Water Pollution Control, University of Natural Resources and Life Sciences Vienna (BOKU), \\ Muthgasse 18, A-1190 Vienna, Austria. \\ *Corresponding author. E-mail: bernhard.pucher@boku.ac.at
}

\begin{abstract}
In this study, the simulation results of four vertical flow wetland systems using the HYDRUS Wetland Module are presented. The four wetland systems comprise three single-stage pilot scale systems and one full-scale two-stage system. The main difference between these systems is the filter media used, referred to as fine media, i.e., sand with a grain size distribution $0.063-4 \mathrm{~mm}$, or coarse media, i.e., sand with grain size distributions between $1-4 \mathrm{~mm}$, respectively. The water-flow simulation of each system is carried out using the single porosity van Genuchten-Mualem model. A good match between measured and simulated volumetric effluent flow rates could be achieved for all wetland systems. For reactive transport simulations, the CW2D biokinetic model was applied. First, simulations were run using the standard CW2D parameter set. For some systems, adjustments of the parameter set were needed in order to avoid unlimited bacteria growth. To better fit measured $\mathrm{COD}, \mathrm{NH}_{4}-\mathrm{N}$, and $\mathrm{NO}_{3}-\mathrm{N}$ effluent concentrations, adjustments of few parameters of the standard parameter set were required. The results show that for the VF wetlands with fine sand, no adjustments of the CW2D standard parameter set were needed, while for systems with coarser filter media as the main layer, the standard parameter set had to be adjusted to match simulated and measured effluent concentrations.
\end{abstract}

Keywords: Treatment wetlands; Vertical flow; French VF wetland; HYDRUS Wetland Module; CW2D.

\section{INTRODUCTION}

In order to improve the understanding of water flow and solute transport, including biological and chemical processes within the soil matrix, the use of software tools like HYDRUS is steadily increasing. With the basic description of water flow in variably-saturated conditions coupled with solute transport, adsorption/desorption processes, geochemical reactions, and biokinetic degradation, a very broad range of applications is available and furthermore extended by various scientific communities (Šimůnek et al., 2016). One implemented module, the HYDRUS Wetland Module (Langergraber and Šimůnek, 2012), was developed in order to simulate the governing biological and chemical transformation and degradation processes of wastewater constituents in subsurface flow treatment wetlands (SSF TW). The field of TW simulation grew consistently over the last decades and has evolved from looking at such systems as a black box to the use of process-based models describing the simultaneous occurring processes responsible for the degradation of various pollutants in the wastewater (Langergraber, 2017; Meyer et al., 2015).

For the treatment of domestic wastewater, SSF TWs are generally applied. Furthermore, SSF TWs can be divided into horizontal flow (HF) and vertical flow (VF) wetlands, whereby in HF wetlands mainly anaerobic and in VF wetlands mainly aerobic processes occur (Kadlec and Wallace, 2009). Two biokinetic model formulations are implemented in the HYDRUS Wetland Module: CW2D (Langergraber and Šimůnek, 2005 ) that describes aerobic and anoxic processes and is mostly used for simulating VF wetlands and CWM1 (Langergraber et al., 2009a) that additionally describes anaerobic processes and is also applicable for HF wetlands. Their mathematical formulation is based on the IWA Activated Sludge Models (Henze et al., 2000).

In this study, simulation results of four different VF TWs are presented and discussed. Two systems are classical single-stage
VF TWs (pilot-scale), one is a full-scale two-stage VF wetland system, and one is a French single-stage VF TW system (pilotscale).

The two-stage VF wetland system is intermittently loaded with mechanically pre-treated wastewater. The first stage consists of a coarse filter media (sand 1-4 mm) for the main layer and has an impounded drainage layer, while the second stage uses a finer sand $(0.063-4 \mathrm{~mm})$ as the main filter layer. This system is designed for full nitrification and high nitrogen elimination. The design is based on the specific area needed with $1 \mathrm{~m}^{2}$ per people equivalent (PE) for each stage, i.e., in total $2 \mathrm{~m}^{2}$ per PE (Langergraber et al., 2008; Langergraber et al., 2009b; Langergraber et al., 2014).

The French VF wetland is also a two-stage VF wetland system but is intermittently loaded with raw wastewater. The main layer of the first stage consists of gravel. The loading of the first stage filter lasts for three to four days and is followed by a resting period twice this time. This is important for the degradation of organic matter and the drying of the sludge layer. The main layer of the second stage consists of sand and treats the percolating water from the first stage (Molle et al., 2005; Paing and Voisin, 2005).

Simulation for the four systems is carried out following the same procedure. Simulation results are compared to measured data and the need for adjustments of model parameter is discussed in relation to the different wetland parameters, i.e., sand used for the main layer, loading regime, etc.

\section{MATERIALS AND METHODS VF wetlands}

A general description of the systems modeled is given in Table 1. Systems 1, 2, and 3 are based on the Austrian system where System 1 (Langergraber, 2001) and 2 (Pucher, 2015) represent the first stage of a $1 \mathrm{~m}^{2}$ pilot-scale system operated in the technical lab hall at the Institute of Sanitary Engineering at 
Table 1. General description of the simulated systems.

\begin{tabular}{|c|c|c|c|c|c|c|c|}
\hline & Size & Wastewater & Filter media & Depth* & Grain size* & Area & Drainage \\
\hline \multicolumn{8}{|c|}{ Single-stage VF wetlands } \\
\hline System 1 & Pilot-scale & Primary treated & Sand & $50 \mathrm{~cm}$ & $0.063-4 \mathrm{~mm}$ & $1 \mathrm{~m}^{2}$ & Free \\
\hline System 2 & Pilot-scale & Primary treated & Sand & $50 \mathrm{~cm}$ & $1-4 \mathrm{~mm}$ & $1 \mathrm{~m}^{2}$ & Impounded \\
\hline \multicolumn{8}{|c|}{ Two-stage VF wetland } \\
\hline System 3 & Full-scale & Primary treated & Sand & $50 \mathrm{~cm}$ & $2-3 \mathrm{~mm}$ & $50 \mathrm{~m}^{2}$ & Impounded \\
\hline \multicolumn{8}{|c|}{ French VF wetland } \\
\hline System 4 & Pilot-scale & Raw & Pea gravel & $40 \mathrm{~cm}$ & $2-4 \mathrm{~mm}$ & $2.3 \mathrm{~m}^{2}$ & Free \\
\hline
\end{tabular}

* of the main layer

Table 2. CW2D processes (Langergraber and Šimůnek, 2012).

\begin{tabular}{lll}
\hline Heterotrophic bacteria & \\
\hline 1 & Hydrolysis & Conversion of CS into CR \\
2 & Aerobic growth of XH on CR & Mineralization of OM \\
3 & Anoxic growth of XH on CR & Denitrification on $\mathrm{NO}_{2}-\mathrm{N}^{\mathrm{X}}$ \\
4 & Anoxic growth of XH on CR & Denitrification on $\mathrm{NO}_{3}-\mathrm{N}$ \\
5 & Lysis of XH & Production of OM \\
\hline Autotrophic bacteria & \\
\hline 6 & Aerobic growth of XANs on $\mathrm{NH}_{4}-\mathrm{N}$ & First step of nitrification \\
7 & Lysis of XANs & Production of OM \\
8 & Aerobic growth of XANb on $\mathrm{NO}_{2}-\mathrm{N}$ & Second step of nitrification \\
9 & Lysis of XANb & Production of OM \\
\hline
\end{tabular}

BOKU University. The third system (Langergraber et al., 2014) is a full-scale two-stage VF wetland system located on a mountain. System 4 (Ruiz et al., 2016) is a single-stage wetland based on the French system.

\section{HYDRUS Wetland Module}

HYDRUS (Šimůnek et al., 2016) numerically solves variably saturated water-flow and solute-transport equations. The water-flow equation incorporates a sink term to account for water uptake by plant roots. The solute-transport equations consider convective-dispersive transport in the liquid phase, diffusion in the gaseous phase, as well as nonlinear nonequilibrium reactions between the solid and liquid phases (Šimůnek et al., 2016). Version 2 of the HYDRUS Wetland Module includes two biokinetic model formulations to simulate the biochemical transformation and degradation processes in TWs: CW2D and CWM1 (Langergraber and Šimůnek, 2012). Up to now, only the single-porosity water-flow model can be used together with the HYDRUS Wetland Module although dual-porosity water-flow models are available within the standard HYDRUS software.

For the simulation of VF wetlands with aerobic conditions, the CW2D biokinetic model is commonly applied (Langergraber, 2017) and therefore CW2D is also chosen for this work. The mathematical formulation of CW2D includes 12 components and nine processes. The components are dissolved oxygen $\left(\mathrm{O}_{2}\right)$, organic matter $(\mathrm{OM})$ divided into readily available $(\mathrm{CR})$, slowly available $(\mathrm{CS})$, and inert organic matter (CI), heterotrophic microorganisms (XH), autotrophic microorganisms (XANs, XANb), nitrogen compounds as ammonium $\left(\mathrm{NH}_{4}-\mathrm{N}\right)$, nitrite $\left(\mathrm{NO}_{2}-\mathrm{N}\right)$, and nitrate $\left(\mathrm{NO}_{3}-\mathrm{N}\right)$ nitrogen, and nitrogen gas $\left(\mathrm{N}_{2}\right)$, as well as inorganic phosphorous $\left(\mathrm{PO}_{4}-\mathrm{P}\right)$ (Langergraber and Šimůnek, 2005). The nine processes described in CW2D are related to the activities of the heterotrophic and autotrophic bacteria groups, respectively (Table 2).

\section{Simulation procedure}

For the two-stage system, each plot was simulated on its own. The simulated effluent concentrations of the first stage have been used as influent concentrations of the second stage (Hochfeldt, 2017). All four VF wetland systems have been calibrated following the same workflow. The water flow was modeled using the standard van Genuchten-Mualem soil hydraulic model (Mualem, 1976; van Genuchten, 1980). Measured soil hydraulic parameters, namely the hydraulic conductivity $K_{s}$, and the saturated water content $\theta_{s}$, as well as the measured boundary flux of each system were used to determine the missing parameters, namely the residual water content $\theta_{r}$ and the form parameters $\alpha$ and $n$, using the inverse solution implemented in HYDRUS, leading to the calibration of the water-flow model.

The reactive transport simulation, including the biokinetic model, was carried out first using the soil and solute specific parameters proposed by Langergraber and Šimůnek (2011) and the standard parameter set of the CW2D module (Langergraber and Šimůnek, 2005). No adsorption processes were considered. The effects of plants, like nutrient uptake, were neglected and a root model was not implemented within the Wetland Module. The influent concentration of COD was fractionalized as follows: CI (inert organic matter) was set to the measured effluent COD concentration while the ratio of readily to slowly biodegradable organic matter, i.e., CR:CS, was 2:1 (Toscano et al., 2009). The adjustment of the biokinetic model parameters was done as follows:

(a) The first adjustment of the parameter set addresses the unlimited growth of the two bacterial groups, $\mathrm{XH}$ and $\mathrm{XANs} / \mathrm{XANb}$, as no growth limiting function is implemented. Therefore the lysis rates $\left[\mathrm{d}^{-1}\right]\left(b_{h}, b_{A N s}, b_{A N b}\right)$ were increased proportionally until a steady state within the model domain was reached (Pálfy et al., 2016; Pucher et al., 2017).

(b) In order to fit the simulated and measured $\mathrm{NH}_{4}-\mathrm{N}$ effluent concentrations, the maximum aerobic growth rate $\mu_{A N s}\left[\mathrm{~d}^{-1}\right]$ of XANs was adjusted. 
(c) In the impounded drainage layer, denitrification occurred. To fit the measured and simulated $\mathrm{NO}_{3}-\mathrm{N}$ effluent concentrations, two parameters needed to be changed. First, the hydrolyses rate $K_{h}\left[\mathrm{~d}^{-1}\right]$ was decreased so that less OM had been degraded in the main layer and more was available for denitrification in the impounded layer as electron donor. Secondly, the maximum denitrification rate $\mu_{D N}\left[\mathrm{~d}^{-1}\right]$ was changed addressing the growth of $\mathrm{XH}$ in the impounded layer under anoxic conditions.

\section{RESULTS AND DISCUSSION}

For all systems, a good match between measured and simulated flow data could be reached (results not shown here but can be found in Hochfeldt (2017), Langergraber (2017), and Pucher et al. (2017)).

Table 3 shows measured and simulated influent and effluent concentrations for all four VF wetland systems. In the first step, simulations were carried out using the standard parameter set of the CW2D biokinetic model (Langergraber and Šimůnek, 2005). These results are referred to as the "standard" parameter set in Table 3. When the match between the simulated and measured effluent concentrations was not sufficient, adjustments to the biokinetic model parameter set were carried out. The adjusted parameters are listed in Table 4 and simulation results are referred to as the "adjusted" parameter set in Table 3. For system 4, no parameter adjustments were performed. For more information on System 4, readers are referred to Pucher et al. (2017).

The fitting procedure was carried out using a trial-and-error approach starting with the growth of the three bacterial groups, namely $\mathrm{XH}$ and XANs/b, in order to get steady-state conditions (Figure 1). System 1 only needed to be adjusted for XH, while System 2 was adjusted for all three. For System 3, no adjustment to the lysis rate was needed (Figure 2). This is explained by the low hydraulic loading based on the event driven operation (Langergraber et al., 2014).

Table 3. Measured and simulated influent and effluent concentrations as mean values; *measurements taken only on the third day of loading.

\begin{tabular}{|c|c|c|c|c|c|c|}
\hline & & & Parameter set & $\begin{array}{c}\mathrm{COD} \\
{\left[\mathrm{mg} \cdot \mathrm{L}^{-1}\right]}\end{array}$ & $\begin{array}{c}\mathrm{NH}_{4}-\mathrm{N} \\
{\left[\mathrm{mg} \cdot \mathrm{L}^{-1}\right]}\end{array}$ & $\begin{array}{r}\mathrm{NO}_{3}-\mathrm{N} \\
{\left[\mathrm{mg}^{\left.-\mathrm{L}^{-1}\right]}\right]}\end{array}$ \\
\hline \multirow[t]{4}{*}{ System 1} & Influent & Measured & & 300 & 60 & 0.1 \\
\hline & Effluent & Measured & & 20 & 0.1 & 37 \\
\hline & & Simulated & Standard & 29 & 0.1 & 56 \\
\hline & & Simulated & Adjusted & \multicolumn{3}{|c|}{ No adjustment required } \\
\hline \multirow[t]{4}{*}{ System 2} & Influent & Measured & & 394 & 93 & 0.59 \\
\hline & Effluent & Measured & & 35 & 14.5 & 70.8 \\
\hline & & Simulated & Standard & 29 & 0.1 & 85.0 \\
\hline & & Simulated & Adjusted & 35 & 13.6 & 83.6 \\
\hline \multirow[t]{7}{*}{ System 3} & Influent & Measured & & 351 & 52.9 & $<0.1$ \\
\hline & Effluent Stage 1 & Measured & & 42 & 14.1 & 0.6 \\
\hline & & Simulated & Standard & 33 & 0.9 & 54.7 \\
\hline & & Simulated & Adjusted & 32 & 16.3 & 5.0 \\
\hline & Effluent Stage 2 & Measured & & $<10$ & $<0.03$ & 12.2 \\
\hline & & Simulated & Standard & 7 & 0.09 & 12.9 \\
\hline & & Simulated & $\begin{array}{c}\text { Adjusted as for stage } \\
1\end{array}$ & 7 & 12.9 & $<0.01$ \\
\hline \multirow[t]{4}{*}{ System 4* } & Influent & Measured & & 850 & 94 & 2 \\
\hline & Effluent & Measured & & 171 & 30 & 38 \\
\hline & & Simulated & Standard & 141 & 3 & 83 \\
\hline & & Simulated & Adjusted & \multicolumn{3}{|c|}{ No adjustments performed } \\
\hline
\end{tabular}

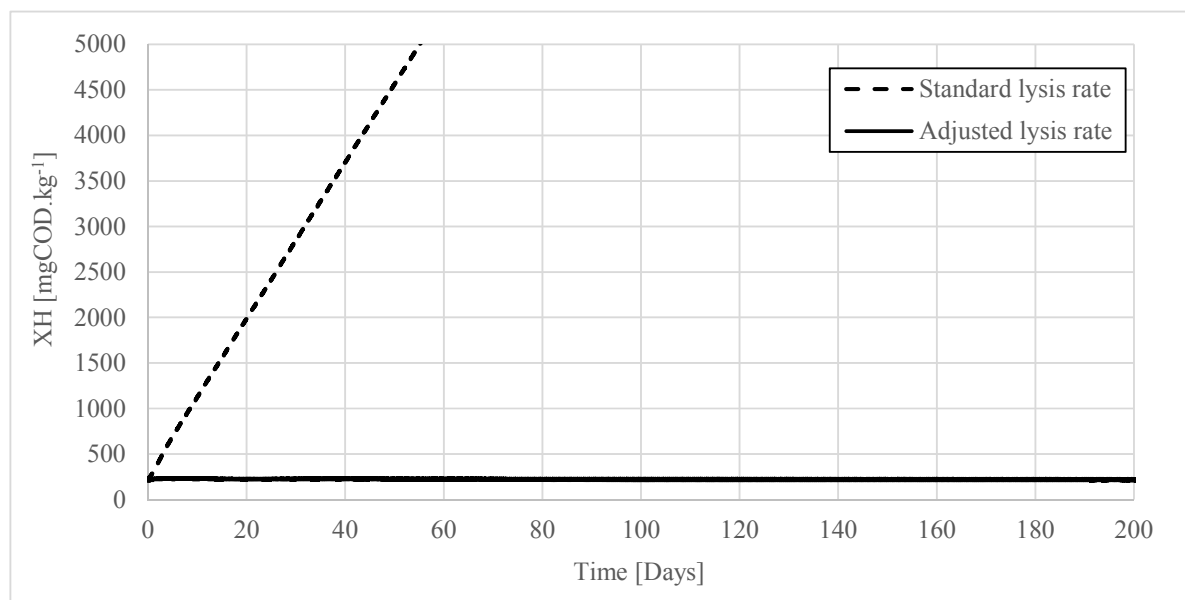

Fig. 1. Effect of the lysis rate adjustment for XH of System 2. 


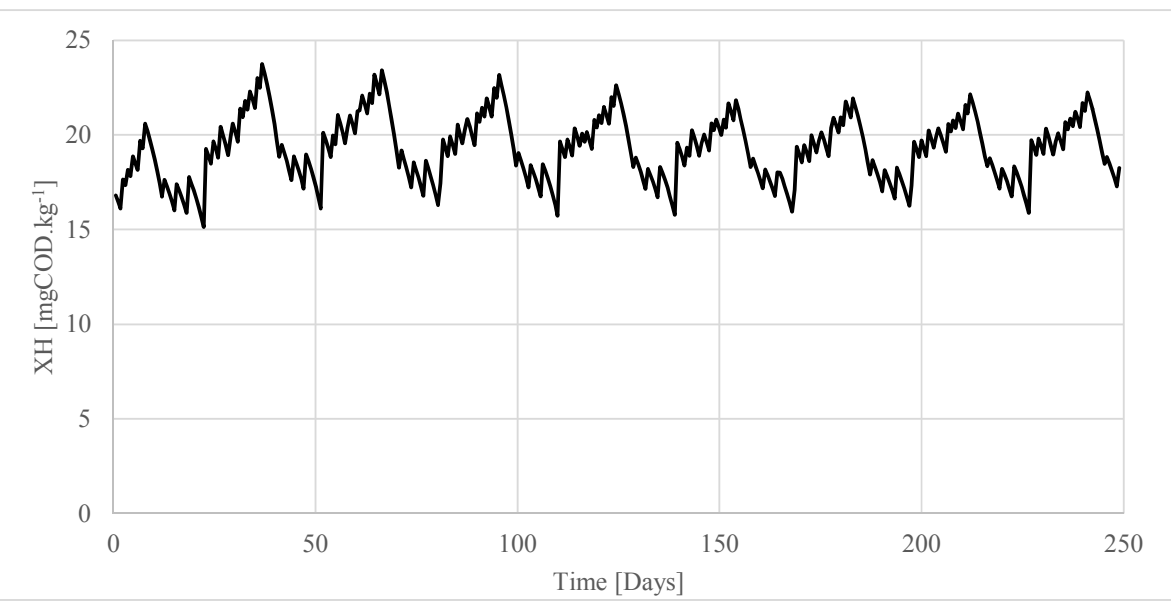

Fig. 2. Steady state conditions of XH growth in Stage 1 of System 3 with the standard value for the lysis rate $b_{H}$.

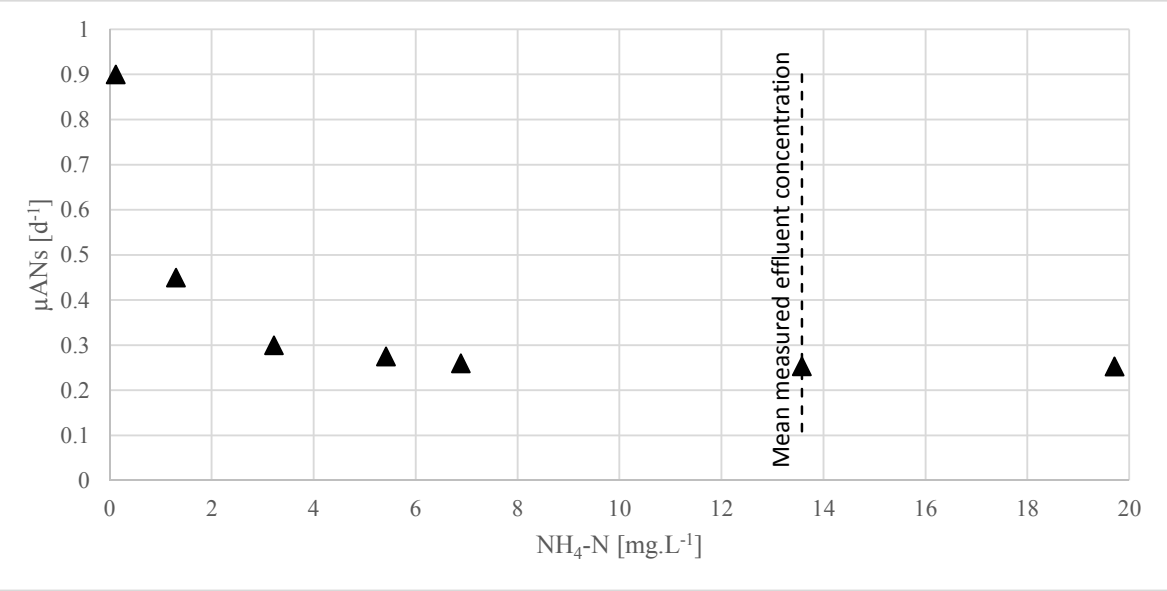

Fig. 3. Effect of decreasing $\mu_{A N S}$ on the simulated $\mathrm{NH}_{4}-\mathrm{N}$ effluent concentration during the fitting procedure of System 2.

Table 4. Comparison of the parameter adjustments required for the CW2D biokinetic model parameters.

\begin{tabular}{|c|c|c|c|c|c|c|}
\hline Parameter & Description & & Standard & System 1 & System 2 & $\begin{array}{l}\text { System } 3 \\
\text { Stage 1 }\end{array}$ \\
\hline$\overline{K_{h}}$ & Hydrolysis rate & {$\left[\mathrm{d}^{-1}\right]$} & 3 & & - & 0.59 \\
\hline$b_{h}$ & Lysis rate for $\mathrm{XH}$ & {$\left[\mathrm{d}^{-1}\right]$} & 0.4 & 0.9 & 0.96 & - \\
\hline$b_{A N S / b}$ & Lysis rate for XANs/b & {$\left[\mathrm{d}^{-1}\right]$} & 0.15 & & 0.216 & - \\
\hline$\mu_{A N S}$ & Maximum aerobic growth rate of XANs & {$\left[\mathrm{d}^{-1}\right]$} & 0.9 & & 0.2538 & 0.18 \\
\hline$\mu_{D N}$ & Maximum denitrification rate of $\mathrm{XH}$ & {$\left[\mathrm{d}^{-1}\right]$} & 4.8 & & - & 60 \\
\hline
\end{tabular}

The fitting of measured and simulated $\mathrm{NH}_{4}-\mathrm{N}$ was carried out by decreasing the maximum nitrifier growth rate $\mu_{A N s}$. The effect of this adjustment is illustrated in Figure 3 for System 2 as an example.

The simulation results for System 1 show that, for systems using the fine-filter material, sand with grain size distribution 0.063-4 mm, no parameter adjustments are needed, while for System 2, using the coarser sand (grain size distribution 1-4 mm), the CW2D standard parameter set overestimates the treatment performance. The same effect can be observed within System 3 using coarser sand with grain size distribution 2-3 $\mathrm{mm}$. When applying the adjusted parameter set from the first stage of System 3 to its second stage (using fine sand with grain size distribution $0.063-4 \mathrm{~mm}$ ), the simulated treatment performance is underestimated. By using the CW2D standard parameter set, a good fit can be achieved for the second stage of System 3.

The difference in the simulation performance between fine and coarse filter media can be explained by the available waterflow model when using the HYDRUS Wetland Module. A comparison between the classical equilibrium flow model and a non-equilibrium model (dual-porosity model) was carried out by Morvannou et al. (2013). When simulating a tracer experiment for the first stage of a French VF wetland system, the dual-porosity model fitted the experiment well, while with the standard equilibrium water-flow model, the tracer couldn't be fitted. These results can be directly compared with the simulation of the treatment performance carried out in this study, as for coarse media a higher performance was simulated than measured. This is explained by the longer contact time between wastewater and biofilm due to the equilibrium flow model. 


\section{CONCLUSION}

Based on the simulation results the following conclusions can be drawn:

- Despite differences in construction and operational conditions of the presented systems, the simulation using the HYDRUS Wetland module gives good results when adjustments to the standard parameter set of the CW2D biokinetic model (Langergraber and Šimůnek, 2005) have been made.

- The most limiting factor in achieving good simulation results using the CW2D standard parameter set is related to the grain size of the filter material used. For fine filter media, the CW2D standard parameter set provides sufficient results, while for coarser media, the treatment performance is overestimated.

- As only single-pore water-flow models can be used with the HYDRUS Wetland Module, only equilibrium-matrix flow is described. Preferential flow paths occurring in coarser media cannot be described and therefore the simulated hydraulic retention time (HRT) is too high, resulting in an overestimation of the pollutant removal.

- It is expected that when coupling a dual-porosity water-flow model with the HYDRUS Wetland Module, better description of the actual water flow, especially preferential flow path and simulated HRT, can be achieved and thus excessive changes of the biokinetic model parameters can be avoided. Finally, it should become possible to simulate measured effluent concentrations for VF wetlands with coarse sand as the main layer using the standard parameter set of the biokinetic model.

\section{REFERENCES}

Henze, M., Gujer,W., Mino, T., Loosdrecht, M., 2000. Activated Sludge Models ASM1, ASM2, ASM2d and ASM3. IWA Publishing, London, UK

Hochfeldt, V., 2017. Numerical simulation of a full-scale twostage constructed wetland system. Master Thesis. University of Applied Sciences Höxter, Germany and University of Natural Resources and Life Sciences, Vienna (BOKU University), Austria.

Kadlec, R.H., Wallace, S.D., 2009. Treatment Wetlands. 2nd ed. CRC Press, Boca Raton, FL, USA.

Langergraber, G., 2001. Development of a Simulation Tool for Subsurface Flow Constructed Wetlands. Ph.D. Thesis. University of Natural Resources and Applied Life Sciences, Vienna (BOKU University), Austria.

Langergraber, G., 2017. Applying process-based models for subsurface flow treatment wetlands: recent developments and challenges. Water, 9, 1, 5 .

Langergraber, G., Šimůnek, J., 2005. Modeling variably saturated water flow and multicomponent reactive transport in constructed wetlands. Vadose Zone Journal, 4, 4, 924-938.

Langergraber, G., Šimůnek, J., 2011. HYDRUS Wetland Module Manual - Version 2. HYDRUS Software Series 4. Department of Environmental Sciences, University of California Riverside, Riverside, CA, USA, $56 \mathrm{p}$.

Langergraber, G., Šimůnek, J., 2012. Reactive transport modeling of subsurface flow constructed wetlands using the HYDRUS Wetland Module. Vadose Zone Journal, 11, 2.

Langergraber, G., Leroch, K., Pressl, A., Rohrhofer, R., Haberl, R., 2008. A two-stage subsurface vertical flow constructed wetland for high-rate nitrogen removal. Water Science and Technology, 57, 12, 1881-1887.

Langergraber, G., Rousseau, D.P.L., García, J., Mena, J. 2009a. CWM1: A general model to describe biokinetic processes in subsurface flow constructed wetlands. Water Science and Technology, 59, 9, 1687-1697.

Langergraber, G., Leroch, K., Pressl, A., Sleytr, K., Rohrhofer, R., Haberl, R., 2009b. High-rate nitrogen removal in a twostage subsurface vertical flow constructed wetland. Desalination, 246, 1-3, 55-68.

Langergraber, G., Pressl, A., Haberl, R., 2014. Experiences from the full-scale implementation of a new two-stage vertical flow constructed wetland design. Water Science and Technology, 69, 2, 335-342.

Meyer, D., Chazarenc, F., Claveau-Mallet, D., Dittmer, U., Forquet, N., Molle, P., Morvannou, A., Pálfy, T., Petitjean, A., Rizzo, A., Samsó Campà, R., Scholz, M., Soric, A., Langergraber, G., 2015. Modelling constructed wetlands: Scopes and aims - a comparative review. Ecological Engineering, 80, 205-213.

Molle, P., Liénard, A., Boutin, C., Merlin, G., Iwema, A., 2005. How to treat raw sewage with constructed wetlands: an overview of the French systems. Water Science and Technology, 51, 9, 11-21.

Morvannou, A., Forquet, N., Vanclooster, M., Molle, P., 2013. Which hydraulic model to use for vertical flow constructed wetlands? In: Šimůnek, J., van Genuchten, M.T., Kodešová, R. (Eds.): Proc. 4th Int. Conf. HYDRUS Software Applications to Subsurface Flow and Contaminant Transport Problems. Dept. of Soil Science and Geology, Czech University of Life Sciences, Prague, pp. 247-257.

Mualem, Y., 1976. A new model for predicting the hydraulic conductivity of unsaturated porous media. Water Resources Research, 12, 3, 513-522.

Paing, J., Voisin, J., 2005. Vertical flow constructed wetlands for municipal wastewater and septage treatment in French rural area. Water Science and Technology, 51, 9, 145-155.

Pálfy, T.G., Molle, P., Langergraber, G., Troesch, S., Gourdon, R., Meyer, D., 2016. Simulation of constructed wetlands treating combined sewer overflow using HYDRUS/CW2D. Ecological Engineering, 87, 340-347.

Pucher, B., 2015. Simulation of vertical flow filters for the treatment of domestic wastewater using sand and zeolite as filter materials. Master Thesis. University of Natural Resources and Applied Life Sciences, Vienna (BOKU University), Austria.

Pucher, B., Ruiz, H., Paing, J., Chazarenc, F., Molle, P., Langergraber, G., 2017. Using numerical simulation of a one stage vertical flow wetland to optimize the depth of a zeolite layer. Water Science and Technology, 75, 3, 650-658.

Šimůnek, J., van Genuchten, M.T., Šejna, M., 2016. Recent developments and applications of the HYDRUS Computer Software Packages. Vadose Zone Journal, 15, 7, 25 p.

Toscano, A., Langergraber, G., Consoli, S., Cirelli, G.L., 2009. Modelling pollutant removal in a pilot-scale two-stage subsurface flow constructed wetlands. Ecological Engineering, 35, 2, 281-289.

van Genuchten, M.T., 1980. A closed-form equation for predicting the hydraulic conductivity of unsaturated soils. Soil Science Society of America Journal, 44, 5, 892-898.

Received 29 June 2017 Accepted 7 September 2017 